\title{
Women's agency in Egypt: construction and validation of a multidimensional scale in rural Minya
}

\author{
Rania Salem, ${ }^{1}$ Yuk Fai Cheong, ${ }^{2}$ Stephanie S. Miedema ${ }^{3}$ and Kathryn M. Yount ${ }^{4}$
}

${ }^{1}$ Department of Sociology, University of Toronto Scarborough, Toronto, Ontario, Canada. ${ }^{2}$ Department of Psychology, Emory University, Atlanta, Georgia, United States of America. ${ }^{3}$ Department of Sociology, Emory University, Atlanta, Georgia, United States of America. ${ }^{4}$ Hubert Department of Global Health \& Department of Sociology, Emory University, Atlanta, Georgia, United States of America. (Correspondence to: Rania Salem: rania.salem@ utoronto.ca).

\begin{abstract}
Background: Measurement of women's agency in specific sociocultural conditions, particularly in Middle Eastern settings, has received limited attention, making its usefulness as an outcome or predictor of gender equality unclear.

Aims: This study aimed to construct and validate a multidimensional and context-specific scale of women's agency in rural Minya, Egypt.

Methods: Using data from 608 ever-married women in 2012, confirmatory and exploratory factor analysis were used to construct a scale measuring women's agency in rural Minya. The scale was validated through exploratory structural equation models.

Results: The 21-item model consisted of three factors (decision-making, freedom of movement and gender role attitudes), each corresponding to a previously-theorized domain of women's agency. The three factors were positively correlated, supporting women's agency as a multidimensional, context-specific construct. The strongest correlation was between decision-making and freedom of movement (0.410), and then between freedom of movement and gender attitudes (0.307); the weakest correlation was between decision-making and gender attitudes (0.211). Although we hypothesized that each domain would be positively associated with age, only decision-making was significantly and positively associated with women's age.

Conclusion: Similarities between the items used here and a study at the national level in Egypt suggest these indicators could be used in various Egyptian settings to monitor progress on the United Nations Sustainable Development Goal 5 on empowering women and girls, and to assess the effect of policies and programmes. Future research should build on the findings to identify the best observable indicators of women's agency in Egypt and elsewhere.

Keywords: women, agency, empowerment, decision-making, factor analysis, Egypt

Citation: Salem R; Cheong YF; Miedema S.S; Yount K.M. Women's agency in Egypt: construction and validation of a multidimensional scale in rural Minya. East Mediterr Health J. 2020;26(6):652-659. https://doi.org/10.26719/2020.26.6.652

Received: 17/03/18; accepted: 01/10/18

Copyright (C) World Health Organization (WHO) 2020. Open Access. Some rights reserved. This work is available under the CC BY-NC-SA 3.0 IGO license (https://creativecommons.org/licenses/by-nc-sa/3.o/igo).
\end{abstract}

\section{Introduction}

Women's agency and the broader concept of women's empowerment have interested social scientists for decades $(1-4)$. Empowerment is the process by which women claim new enabling resources, such as schooling, employment and extra-familial support. These resources, in turn, may enhance women's agency $(1,5,6)$, or ability to "define their own life-choices and to pursue their own goals, even in the face of opposition from others" (1, page 438). Resources and agency are thus multidimensional domains of the overarching construct of women's empowerment.

Measures of women's agency have been associated in different contexts with contraceptive use $(7,8)$, and improved child health and nutrition (9-12). Therefore, clarifying the dimensions of women's agency in local contextsandstandardizingapproachestoitsmeasurement are important priorities for policy and research. It is important to measure women's empowerment generally, and women's agency specifically, to monitor progress towards achieving United Nations Sustainable
Development Goal (SDG) 5: to achieve gender equality and empower all women and girls (13). In spite of the need to measure agency effectively for policy and scholarship, its operationalization and measurement have varied, and the choice of items to include has been ad hoc, poorly justified and inadequately described (3).

As conceptualized by existing research, women's agency is multidimensional $(1,3,4,14)$ and context-specific (15). However, some researchers have operationalized agency as unidimensional and constructed measures of agency by summing responses to survey items into a single scale (16). Others have used summary measures of single domains, such as women's decision-making or their contributions to household income, as a proxy for overall agency $(17,18)$. Only a few studies have used advanced statistical methods to examine the latent structure of women's agency (e.g. numbers of factors and relationships between them), while accounting for measurement error and permitting differential weights for observed items (5,6,19-23). Advanced statistical methods, such as factor analysis, allow factor scores for 
the multiple domains of agency to be created, which can be analysed in research on the determinants and effects of each domain of women's agency. Such approaches have advantages over single summative score measures of women's agency, which do not account for measurement error and which may hide patterns of association between the domains of agency and other important variables (20). Single summative approaches thus obscure the pathways through which agency and empowerment operate (20).

Problematically, some measures of agency also ignore its context specificity. Prevailing theories of women's empowerment - within which agency is one domain - highlight the relevance of the environment and contextual factors in which women take actions characterized by agency (1). However, emerging evidence suggests that some items that measure women's agency are context-specific while others apply across contexts (19). Still, because of geographical variation in indicators of women's agency (7,24,25), context-appropriate measurement models are needed.

Research has shown how prevailing forms of classic patriarchy in Egypt affect women's agency (26). Women exchange obedience to male guardians for economic support, physical protection, social respectability and eventual authority over junior women. Important household decisions fall to senior men and women are expected to accept their subordination and adopt attitudes that devalue women and elevate men. Women limit their interactions with unrelated men for reasons of sexual purity, a concern also used to justify their restricted physical mobility.

In Egypt, factor analysis has been used to construct scales that capture women's influence in family decisions (27) and to explore the multidimensional nature of women's empowerment (28). More recently, a construct for Egyptian women's agency was psychometrically tested which consisted of three domains: influence in family decision-making (decision-making), freedom of movement in public (freedom of movement), and vocalization of more equitable gender attitudes (gender attitudes) (6). In this study, we aimed to determine how well these three measures capture agency (defined as women's exercise of choice in these three specific domains) in the context of the socially conservative, resource-poor setting of rural Minya, Egypt. In addition, we used factor analysis to explore and confirm a multidimensional and context-specific scale of women's agency in rural Minya. Finally, we assessed the construct validity of the measure by assessing whether women's age was associated in expected ways with each of the three domains of women's agency.

Our examination of the factor structure of women's agency was informed by previous studies of this construct in Egypt $(2,6,16,27,28)$, but it is distinct in its focus on multidimensionality, item selection and retention, and model fit. Based on theory and earlier research $(1,3,6,14)$, we hypothesized that women's agency was a multidimensional construct, and that the domains of women's agency were positively correlated. To assess the construct validity of the multidimensional measure, we further hypothesized that age would be positively associated with decision-making, because women gain authority with age $(26,27)$. Similarly, we expected a positive association between women's age and freedom of movement, as rural Egyptian women may go more places and are less frequently accompanied as they age (26). Lastly, we anticipated that the oldest and youngest women would have the least equitable gender attitudes, as older women had grown up at a time when gender norms were more patriarchal, and younger women, having less authority in the family, may be less likely to challenge custom (26).

\section{Methods}

\section{Setting and sample}

Our study was conducted in rural Minya (29), a governorate located approximately $250 \mathrm{~km}$ south of Cairo. Minya had a population of 4.3 million in $2010,81.1 \%$ of whom lived in rural areas (30). Social conservatism, lack of material resources, limited government investment, and poor infrastructure make Minya a socio-culturally distinct region of Egypt and a useful site to assess the applicability of measurement indicators for women's agency.

Women from rural Minya interviewed in the 2005 Egypt Demographic and Health Survey were eligible to participate in a 2012 follow-up survey (29). In the 2005 Demographic and Health Survey, 1122 ever-married women aged 15-49 years in rural Minya completed the women's questionnaire; of these, 328 from a one-third subset of households completed a module on experiences of intimate partner violence. For the 2012 follow-up survey, we included these 328 women, and randomly selected another 514 households (29), from which we chose one woman per household using the Kish method (31), for a total follow-up sample of 842 women. We were able to find and interview 608 of the 842 selected women, a follow-up response rate of $72 \%$. We conducted the follow-up survey from November 2011 to April 2012 (29). Questionnaire items drew on questions used in previous surveys in Egypt and other resource-poor settings, and were extensively pretested using qualitative and cognitive interviewing methods. Respondents were interviewed by trained female field researchers, who recorded answers using pencil-and-paper questionnaires. As much as possible, interviews were conducted in private, usually in the homes of the respondents.

\section{Measures of women's agency}

Our choice of items to operationalize women's agency was based on theory, empirical research, and preliminary analyses of the 2012 survey data. The 29 items initially included represented one of four domains of women's agency: decision-making, freedom of movement, gender attitudes and political participation or political agency. Four items representing political agency were removed for reasons described in the analysis section. Descriptive statistics for the 25 remaining indicators are presented in Table 1. 


\begin{tabular}{|c|c|c|c|c|}
\hline \multirow{2}{*}{$\begin{array}{l}\text { Domain } \\
\text { Decision-making (DM) }\end{array}$} & \multirow[t]{2}{*}{ Item } & \multicolumn{3}{|c|}{ Response categories ${ }^{a, b}$} \\
\hline & & & & \\
\hline \multicolumn{2}{|l|}{ Who in your family has the final say in purchasing the following things? } & Someone else & You and someone else & You \\
\hline Vegetables and fruit & DM_1 & 12 & 13 & 75 \\
\hline Clothes for yourself & DM_2 & 20 & 22 & 57 \\
\hline Any kind of medicine for yourself & DM_3 & 24 & 28 & 48 \\
\hline Toiletries for yourself & DM_4 & 21 & 19 & 60 \\
\hline Large household purchases & DM_5 & 42 & 45 & 13 \\
\hline \multicolumn{2}{|l|}{ Who in your family usually makes the following decisions/has the final say in the following matters? } & Someone else & You and someone else & You \\
\hline Health care for yourself & DM_6 & 19 & 58 & 23 \\
\hline Large household purchases ${ }^{c}$ & DM_7 & 30 & 58 & 12 \\
\hline Purchases for daily household needs ${ }^{c}$ & DM_8 & 13 & 42 & 45 \\
\hline Your visits to your family or relatives & DM_9 & 20 & 57 & 23 \\
\hline Whether or not you will work to earn money & DM_10 & 26 & 66 & 08 \\
\hline \multicolumn{5}{|l|}{ Freedom of movement (FM) } \\
\hline \multicolumn{2}{|l|}{ Are you allowed to go to the following places? } & Never & Not alone & Alone \\
\hline Local market to buy things & FM_1 & 2 & 23 & 75 \\
\hline Local health centre or doctor & FM_2 & 1 & 25 & 74 \\
\hline Homes of your friends in the neighbourhood & FM_3 & 1 & 22 & 77 \\
\hline Nearby mosque or church & FM_4 & 6 & 25 & 69 \\
\hline \multicolumn{5}{|l|}{ Gender attitudes (GA) } \\
\hline \multicolumn{2}{|l|}{ In your opinion is a husband justified in hitting his wife in the following situations } & Yes & Don't know & No \\
\hline She goes out without telling him & GA_1 & 57 & 0 & 43 \\
\hline She neglects the children & GA_2 & 46 & 0 & 53 \\
\hline She argues/debates with him ${ }^{c}$ & GA_3 & 34 & 0 & 66 \\
\hline She refuses to have sex with him & GA_4 & 54 & 4 & 42 \\
\hline She burns the food & GA_5 & 24 & 1 & 75 \\
\hline \multicolumn{2}{|l|}{ Please tell me if you agree or disagree with each statement } & Agree & Don't know & Disagree \\
\hline $\begin{array}{l}\text { If a wife is working outside the home, then her husband should help her with household } \\
\text { chores and raising the children }\end{array}$ & GA_6 & 74 & 6 & 20 \\
\hline A wife should be allowed to work outside the home if she wants to ${ }^{c, d}$ & GA_7 & 78 & 7 & 16 \\
\hline $\begin{array}{l}\text { A wife has a right to express her opinion even when she disagrees with what her husband } \\
\text { is saying }\end{array}$ & GA_8 & 72 & 10 & 18 \\
\hline The important decisions of the family should be made only by a husband & GA_9 & 64 & 4 & 32 \\
\hline A wife should tolerate being hit by her husband in order to keep the family together & GA_10 & 40 & 7 & 52 \\
\hline $\begin{array}{l}\text { If a family doesn't have enough money to send all the children to school, it is better to } \\
\text { send a son to school than a daughter }\end{array}$ & GA_11 & 15 & 8 & 77 \\
\hline
\end{tabular}

\section{Analysis}

Because of earlier theoretical and empirical support for women's agency as a multidimensional construct $(1,20,27)$, we began with confirmatory factor analysis. We matched many of our items with those used in previous exploratory factor analyses/confirmatory factor analyses and added four items measuring political agency. However, when we ran a confirmatory factor analysis with a four-factor combined model, the results showed poor model fit. On further inspection, one of the four items for political agency showed little variability and was removed. This left three, possibly too few to represent political agency in a confirmatory factor analysis model (32). Therefore, we removed political agency and ran a three-factor confirmatory factor analysis. The results again showed modest model fit (root mean square error of approximation $=0.067$, comparative fit index $=0.915$ and Tucker-Lewis index $=0.906$ ), and modification indices suggested significant cross-loadings. Following the recommended approach when the a priori specified confirmatory factor analysis model does not fit (32), we ran an exploratory factor analysis, excluding the four items for political agency.

In the first step of the exploratory factor analysis, we 
examined the frequency distributions of the remaining 25 items. We estimated all measurement models using Mplus 7 (33) with mean and variance-adjusted weighted least squares estimators, appropriate for estimating exploratory factor analysis models with ordinal data. For ordinal items, the weighted least squares estimator computes a polychoric correlation matrix and uses it to fit the exploratory factor analysis model. The program calculated standard errors and chi-squared tests of model fit accounting for the survey's complex sampling design, including clustering and unequal probability of selection (33).

Our exploratory factor analysis proceeded sequentially. First, we ran the exploratory factor analysis with all 25 items and examined and interpreted the scree plots, model fit indices and factor pattern loadings after geomin (oblique) rotation for models with one to five factors. We chose oblique rotation because, unlike the orthogonal ones such as the varimax rotation, it allowed the factors to be correlated. We expected the women's agency factors identified to be correlated. The geomin rotation, the default approach adopted by Mplus (33), is the preferred approach over other oblique rotation methods when the goal is to search for solutions with smaller cross-loadings and large associations between factors (34). Results of the model fit indices - root mean square error of approximation = 0.048 , comparative fit index $=0.967$ and Tucker-Lewis index $=0.952$ - indicated an excellent fit for the four-factor model. However, it had four items with negative loadings $\leq-0.300$ on one factor, but positive loadings on others. These negative loadings were inconsistent with existing theory, as all items were expected to load positively on the domains of women's agency.

As we wanted to identify the smallest set of items measuring domains of women's agency in rural Minya, we removed three negatively loading items one at a time, beginning with the most negatively loading item $(32,35)$. The items eliminated included one related to gender attitudes (GA_3) and two related to decision-making (DM_7, DM_8) (Table 1). While it is unclear why they had negative factor loadings, the ordering and phrasing of the questions may have been problematic.

Next, based on methodological precedent and the theoretical perspective that women's agency has multiple correlated but distinct domains, we removed items with cross-loadings (substantive loadings $\geq 0.300$ ) on more than one factor (35). Beginning with the item with the highest cross-loading relative to its primary factor loading, we removed gender attitudes item GA_7 (Table 1). We then ran an exploratory factor analysis model with 21 items, comparing the fit of models with one to five factors. Results of the root mean square error of approximation (0.057), comparative fit index (0.964) and Tucker-Lewis index (0.949) indicated good model fit for the three-factor model. While the root mean square error of approximation (0.049), comparative fit index (0.976), and Tucker-Lewis index (0.962) demonstrated a better fit for the four-factor model, the scree test (Figure 1) supported a three-factor solution. Moreover, while the three-factor solution had no items with cross-loadings $\geq$ 0.300 , the four-factor solution had four items with crossloadings $\geq 0.300$. Apart from the cross-loading items, the fourth factor had only two items with factor loadings $\geq$ 0.300 , suggesting a weak factor (32). Based on these results and our goal of identifying the most parsimonious set of items, the three-factor model was more suitable.

In a final step, we explored the construct validity of our measure. We added three categorical covariates for women's age (30-39 years, 40-49 years, 50-65 years, reference 20-29 years) to an exploratory structural

Figure 1 Scree plot for the final model of women's agency, rural Minya, Egypt

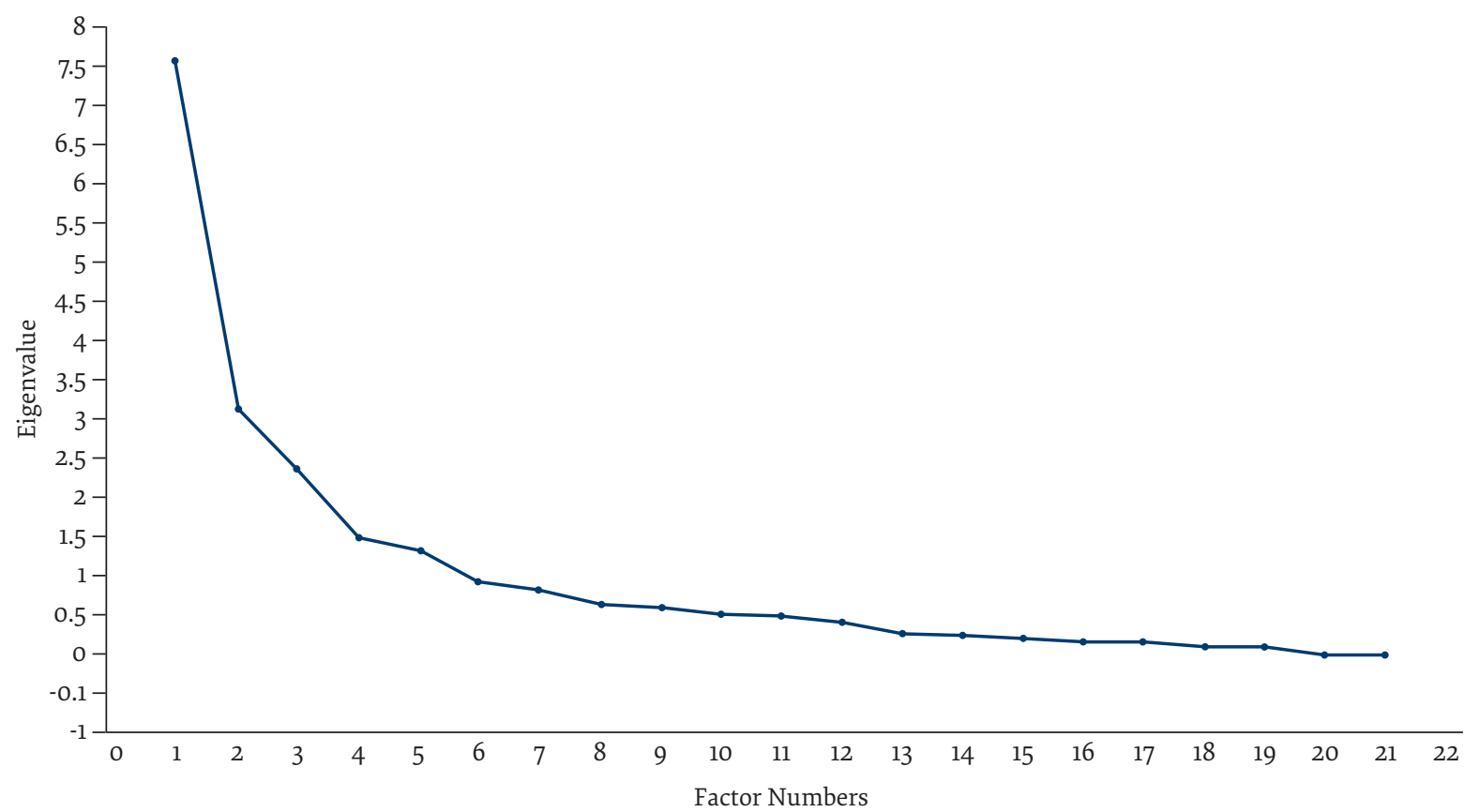


equation model, specifically an exploratory factor analysis model with covariates, to assess the association of women's age with each of the three domains of women's agency.

\section{Results}

\section{Descriptive statistics}

Table 1 shows descriptive statistics for indicators of women's agency according to each of the final three domains.

\section{Exploratory factor analysis}

Geomin rotated factor loadings for the final three-factor model (available upon request) showed that 10 items had significant $(P \leq 0.05)$ geomin rotated factor loadings $\geq$ 0.300 on the first factor. The items loading on it included all eight decision-making items, all with factor loadings $\geq$ 0.481. Two gender attitude items (GA_6, GA_8) also loaded on the first factor, but with lower factor loadings ( 0.375 and 0.396 , respectively) than the decision-making items. Based on the pattern of factor loadings, we called the first factor the decision-making factor. All four freedom of movement items had high factor loadings (0.810-0.904, $P$ $\leq 0.05$ ) on the second factor (freedom of movement factor). Seven gender attitude items had significant $(P \leq 0.05)$ factor loadings on the third factor (gender attitudes factor). The four items measuring women's justification of intimate partner violence (GA_1, GA_2, GA_4, GA_5) had high factor loadings (0.842-0.949). The three representing patriarchal gender attitudes (GA_9, GA_10, GA_11) had lower factor loadings (0.361-0.454).

Geomin factor correlations between the three domains of women's agency in the final three-factor model (available upon request) showed that all three factors were positively correlated (significant at $P \leq 0.05$ ). The strongest correlation was between decision-making and freedom of movement (0.410), the next strongest correlation was between freedom of movement and gender attitudes (0.307) and the weakest correlation was between decision-making and gender attitudes (0.211).

\section{Construct validation}

Table 2 shows the associations between women's age and domains of women's agency. Older women reported higher levels of decision-making than younger women (20-29 years). This relationship was significant for women 50-65

$\begin{aligned} & \text { Table } 2 \text { Exploratory structural equation modelling of } \\
& \text { associations between women's age and domains of women's } \\
& \text { agency }\end{aligned}$
\begin{tabular}{llll}
\hline $\begin{array}{l}\text { Age } \\
\text { (years) }\end{array}$ & $\begin{array}{c}\boldsymbol{\beta} \text { for decision- } \\
\text { making (SE) }\end{array}$ & $\begin{array}{c}\boldsymbol{\beta} \text { for freedom of } \\
\text { movement (SE) }\end{array}$ & $\begin{array}{c}\boldsymbol{\beta} \text { for gender } \\
\text { attitudes (SE) }\end{array}$ \\
\hline $20-29$ (ref) & $0.165(0.123)$ & $0.170(0.149)$ & $-0.017(0.131)$ \\
$30-39$ & $0.257 \dagger(0.134)$ & $0.095(0.150)$ & $-0.076(0.116)$ \\
$40-49$ & $0.406^{*}(0.157)$ & $-0.166(0.183)$ & $-0.093(0.162)$ \\
$50-65$ &
\end{tabular}

SE: standard error, ref: reference category.

$\dagger P \leq 0.10,{ }^{*} \mathrm{P} \leq 0.05$ years $(\beta=0.406, P \leq 0.05)$, and marginally significant for women $40-49$ years $(\beta=0.257, P \leq 0.10)$. We did not find significant associations between women's age and freedom of movement or gender attitudes.

\section{Discussion}

Our study contributes to previous literature by using exploratory factor analysis to examine the multidimensional measurement of women's agency in a rural Middle Eastern context. It expands on existing efforts to measure women's agency nationally in Egypt (6), testing measurement models in a largely rural, conservative context. Using a set of questionnaire items similar to those used in a national-level analysis (6), three similar domains captured underlying aspects of women's agency: decision-making, freedom of movement and gender attitudes. Each corresponds to a well-theorized domain of agency identified as an important aspect of women's agency in previous studies in Egypt $(2,6,16,27,28,36,37)$. Our analysis reflects the multidimensional nature of women's agency, unlike earlier efforts to capture agency and related constructs in Egyptian women using single summative indices (16). Our analysis also offers greater parsimony than the only other effort to use factor analysis to develop a multidimensional construct similar to women's agency in Egypt (28), prior to the national validation study mentioned above (6).

Although the number of factors emerging from the national-level analysis (6) is the same as ours, the underlying structure of women's agency differs. Specifically, two factors in the national analysis (women's gender attitudes and freedom of movement) were not significantly correlated (6), whereas all three factors were positively correlated in our current analysis. This difference may reflect that the national analysis exclusively used attitudes related to gender-based violence rather than attitudes to women's roles and rights (6). The difference in the contribution of these attitudes to the latent structure of agency should be investigated further using psychometric testing.

In our exploratory factor analysis, items measuring women's agreement (or not) with patriarchal gender norms (GA_06 to GA_11) did not follow anticipated patterns. Whether these items sufficiently represent women's gender attitudes in the context of rural Egypt remains unclear and should be explored in future analyses.

Women's older age, as anticipated, was positively associated with decision-making, but not with freedom of movement and gender attitudes. These findings are best interpreted in light of the patriarchal context in which rural Egyptian women exercise agency; older women have authority over younger ones and more say in household decisions. In contrast, the non-significant association between age and freedom of movement may be because women understood these to relate to actual mobility, and not whether they are allowed to go to various places. We recommend future measures of women's freedom of movement state simply: "if 
you wanted to, could you go to the following places ... (never, with permission, without permission)." Finally, and unexpectedly, women's age was not associated with gender attitudes. Future research should explore the relationship between this domain of agency and other covariates, such as higher education.

In addition to modifying the freedom of movement items, the measurement of women's agency in rural Egypt could be improved in other ways. Currently, the measurement model does not capture additional domains of women's agency, such as political agency, which may be appropriate for the rural Egyptian context but was poorly measured with the items we had. Likewise, the items for decision-making may reflect "feminine" or relegated domains of decision-making under classic patriarchy (27), and may not capture the full scope of women's decision-making agency in arenas reserved for men. Qualitative research should develop items to explore these and other emerging domains of women's agency in rural Egypt.

Our results carry implications for research and policy in Egypt and internationally. Although there is some overlap, the items we used to measure women's agency differ somewhat from those used to measure similar constructs in south and south-east Asia (20-22), limiting the possibility for comparative research. However, as many of the items used in our analysis may be found in the women's status modules of various demographic and health surveys (38), our detailed description of item selection and retention may guide efforts to measure women's agency in different national contexts in future research. Our analysis thus contributes to a growing global conversation about how to measure women's agency and similar constructs $(37,39)$. Policies and programmes also may benefit from our analysis. The domains captured by our measure of agency include examples of factors that might impede women from accessing interventions offered in public spaces (lack of freedom of movement), factors that might be necessary conditions for interventions to succeed (equitable gender attitudes), and factors that could be the target outcomes of interventions (greater decision-making within the household). In the absence of methodologically systematic and theoretically grounded approaches to measuring women's agency, it will be difficult to determine which interventions effectively achieve the broader objective of empowering women and girls and their attainment of gender equality. Sound approaches to measuring women's agency are needed to monitor progress and to assess the impacts of the policies and programmes in which countries are investing in order to achieve SDG 5 .

\section{Acknowledgements}

We thank Kristin VanderEnde for her contributions to earlier versions of this paper.

Funding: The parent study on which this analysis is based was funded by the United Nations Development Programme and the Gender Economic Research and Policy Analysis Programme of the World Bank (principal investigator: Dr Kathryn M. Yount).

Competing interests: None declared.

\section{Le pouvoir d'agence des femmes en Égypte : établissement et validation d'une échelle multidimensionnelle dans la région rurale de Minya}

\section{Résumé}

Contexte : La mesure du pouvoir d'agence des femmes dans des conditions socioculturelles spécifiques, en particulier au Moyen-Orient, n'a fait l'objet que de peu d'attention; de ce fait, son utilité en tant que résultat ou que facteur prédictif n'est pas claire.

Objectifs : La présente étude avait pour objectif d'établir et de valider une échelle multidimensionnelle et spécifique au contexte du pouvoir d'agence des femmes dans la région rurale de Minya en Égypte.

Méthodes : Sur la base de données recueillies en 2012 auprès de 608 femmes mariées ou l'ayant été, des analyses factorielles confirmatoire et exploratoire ont été utilisées pour mettre au point une échelle permettant d'évaluer le pouvoir d'agence des femmes dans la région rurale de Minya. L'échelle a été validée à l'aide de modèles d'équations structurelles exploratoires.

Résultats : Le modèle constitué de 21 items comprenait trois facteurs (prise de décisions, liberté de mouvement et attitudes sexospécifiques) qui correspondaient chacune à un domaine précédemment théorisé se rapportant au pouvoir d'agence des femmes. Les trois facteurs étaient corrélés positivement, confirmant le pouvoir d'agence des femmes en tant que concept multidimensionnel et spécifique au contexte. La corrélation la plus forte était celle entre la prise de décisions et la liberté de mouvement $(0,410)$, puis entre la liberté de mouvement et les attitudes sexospécifiques $(0,307)$; la corrélation la plus faible étant celle entre la prise de décisions et les attitudes sexospécifiques $(0,211)$. Bien que l'on ait émis l'hypothèse que chaque domaine serait positivement associé à l'âge, seule la prise de décisions a été corrélée de manière significative et positive à l'âge des femmes.

Conclusions : Les similitudes entre les items utilisés ici et une étude menée au niveau national en Égypte laissent penser que ces indicateurs pourraient être utilisés dans divers contextes égyptiens pour suivre les progrès de la réalisation de l'Objectif 5 du développement durable sur l'autonomisation des femmes et des filles, et évaluer l'impact des politiques et des programmes. Les recherches futures devraient s'appuyer sur ces conclusions pour identifier les meilleurs indicateurs observables du pouvoir d'agence des femmes en Égypte et ailleurs. 


\section{تمكين المر أة في مصر : إنشاء مقياس متعدد الأبعاد والتحقُّ منه في ريف محافظة المنيا}

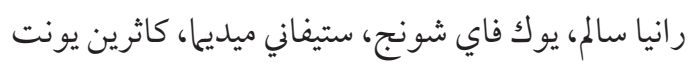

$$
\begin{aligned}
& \text { الخلفية: هناك أبحاث محدودة أُجريت لقياس تمكين المر أة في ظل أوضاع اجتماعية وثقافية محددة، لا سيا في السياقات الشرق أوسطية. }
\end{aligned}
$$

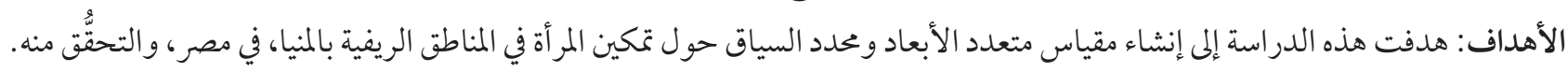

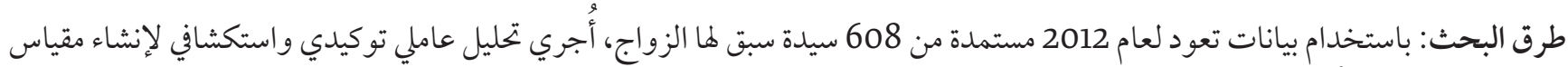

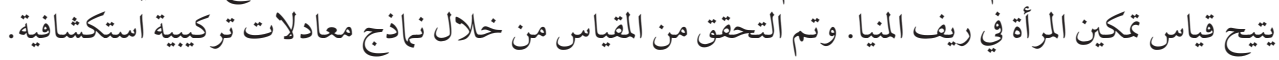

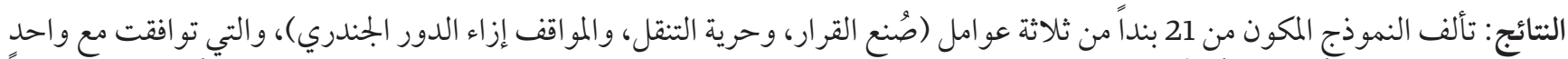

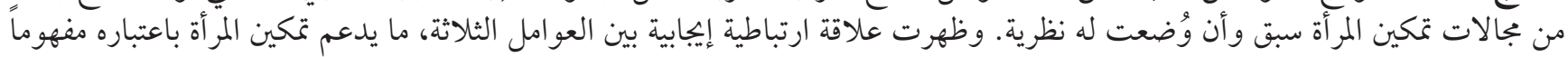

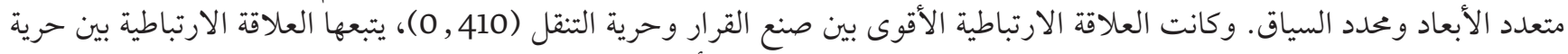

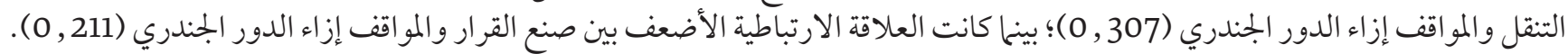

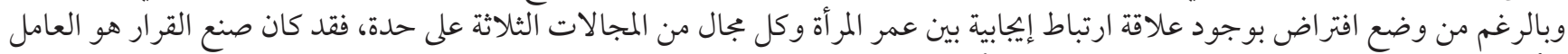
الأوحد الذي ارتبط بصورة جوضر اضورية وإيجابية بعمر المرأة.

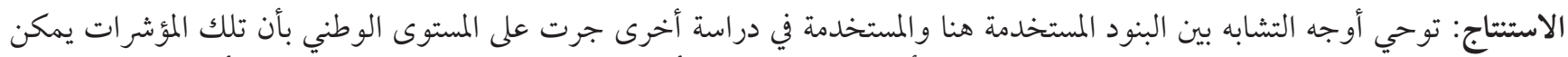

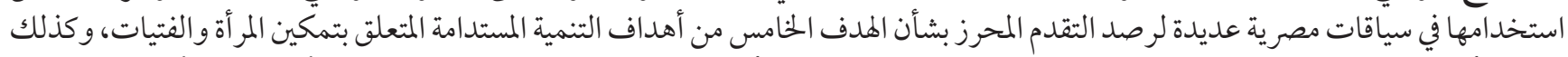

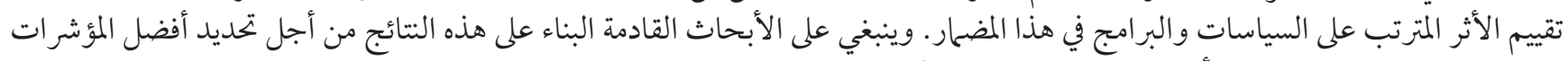
القابلة للملاحظة حول تمكين المرأة في مصر وفي غير التها من البُلدان.

\section{References}

1. Kabeer N. Resources, agency, achievements: reflections on the measurement of women's empowerment. Dev Change. 1999;30(3):435-64. http://doi.org/10.1111/1467-7660.00125

2. Kishor S. Autonomy and Egyptian women: Findings from the 1988 Egypt Demographic and Health Survey. Calverton, Maryland: Macro International; 1995.

3. Malhotra A, Schuler SR. Women's empowerment as a variable in international development. In: Narayan D, editor. Measuring empowerment: cross-disciplinary perspectives. Washington (DC): World Bank; 2005:71-88.

4. Mason KO. The status of women: conceptual and methodological issues in demographic studies. Sociol Forum. 1986;1:284-300. http://doi.org/10.2307/684447

5. Salem R, Cheong YF, Yount KM. Is women's work a pathway to their agency in rural Minya, Egypt? Soc Indic Res. 2018;136(2):807-31. http://doi.org/10.1007/s11205-017-1573-9.

6. Yount KM, VanderEnde KE, Dodell S, Cheong YF. Measurement of women's agency in Egypt: a national validation study. Soc Indic Res. 2016;128(3):1171-92. http://doi.org/10.1007/s11205-015-1074-7

7. Bogale B, Wondafrash M, Tilahun T, Girma E. Married women's decision making power on modern contraceptive use in urban and rural southern Ethiopia. BMC Public Health. 2011;11(1):342-9. http://doi.org/10.1186/1471-2458-11-342

8. Leon FR. Predicting contraceptive use from an egalitarian model of women's overall household power vis-a-vis conventional power models and third variables. J Biosoc Sci. 2013;45(4):497-515. http://doi.org/10.1017/So021932012000624

9. Smith LC, Ramakrishnan U, Ndiaye A, Haddad L, Martorell R. The importance of women's status for child nutrition in developing countries. Washington (DC): International Food Policy Research Institute; 2003.

10. Hossain MB, Phillips JF, Pence B. The effect of women's status on infant and child mortality in four rural areas of Bangladesh. J Biosoc Sci. 2007;39(3):355-66. http://doi.org/10.1017/S002193200600143X

11. Shroff M, Griffiths P, Adair L, Suchindran C, Bentley M. Maternal autonomy is inversely related to child stunting in Andhra Pradesh, India. Matern Child Nutr. 2009;5(1):64-74. http://doi.org/10.1111/j.1740-8709.2008.00161.x

12. Shroff M, Griffiths P, Suchindran C, Nagalla B, Vazir S, Bentley ME. Does maternal autonomy influence feeding practices and infant growth in rural India? Soc Sci Med. 2011;73(3):447-55. http://doi.org/10.1016/j.socscimed.2011.05.040

13. Sustainable Development Goal 5: achieve gender equality and empower all women and girls. New York: United Nations; 2019 (https://sustainabledevelopment.un.org/sdg5, accessed 14 January 2020).

14. Mogford, E. When status hurts: dimensions of women's status and domestic abuse in rural Northern India. Violence Against Women. 2011;17(7):835-57. http://doi.org/10.1177/1077801211412545 
15. Smith SN, Fisher SD, Heath A. Opportunities and challenges in the expansion of cross-national survey research. Int J Soc Res Methodol. 2011;14(6):485-502. http://doi.org/10.1080/13645579.2011.611386

16. Nawar L, Lloyd C, Ibrahim B. Women's autonomy and gender roles in Egyptian families. In: Obermeyer CM, editor. Family, gender, and population in the Middle East: policies in context. Cairo: American University in Cairo Press; 1995:147-78.

17. Kantor P. Women's empowerment through home-based work: evidence from India. Dev Change. 2003;34(3):425-45. http://doi. org/10.1111/1467-7660.00313

18. Upadhyay UD, Hindin MJ. Do higher status and more autonomous women have longer birth intervals? Results from Cebu, Philippines. Soc Sci Med. 2005;60(11):2641-55. http://doi.org/10.1016/j.socscimed.2004.11.032

19. Miedema SS, Haardörfer R, Girard AW, Yount, KM. Women's empowerment in East Africa: development of a cross-country comparable measure. World Dev. 2018;110:453-64. http://doi.org/10.1016/j.worlddev.2018.05.031

20. Agarwala R, Lynch SM. Refining the measurement of women's autonomy: an international application of a multi-dimensional construct. Soc Forces. 2006;84(4):2077-98. http://doi.org/10.1353/sof.2006.0079

21. Ghuman SJ, Lee HJ, Smith HL. Measurement of women's autonomy according to women and their husbands: results from five Asian countries. Soc Sci Res. 2006;35(1):1-28. http://doi.org/10.1016/j.ssresearch.2004.06.001

22. Steele F, Goldstein H. A multilevel factor model for mixed binary and ordinal indicators of women's status. Sociol Methods Res. 2006;35(1):137-53. http://doi.org/10.1177/0049124106289112

23. Williams J. Measuring gender and women's empowerment using confirmatory factor analysis. Boulder (CO): Population Program, Institute of Behavioral Science, University of Colorado; 2005.

24. Koenig MA, Ahmed S, Hossain MB, Mozumder ABM. Women's status and domestic violence in rural Bangladesh: individualand community-level effects. Demography. 2003;40(2):269-88. http://doi.org/10.1353/dem.2003.0014

25. Mistry R, Galal O, Lu M. Women's autonomy and pregnancy care in rural India: a contextual analysis. Soc Sci Med. 2009;69(6):926-33. http://doi.org/10.1016/j.socscimed.2009.07.008

26. Kandiyoti D. Bargaining with patriarchy. Gend Soc. 1988;2(3):274-90. http://doi.org/10.1177/089124388002003004

27. Yount KM. Women's family power and gender preference in Minya, Egypt. J Marriage Fam. 2005;67(2):410-28. https://www. jstor.org/stable/3600278

28. Kishor S. Empowerment of women in Egypt and links to the survival and health of their infants. In: Presser H, Sen G, editors. Women's empowerment and demographic processes: moving beyond Cairo. New York: Oxford University Press; 2000.

29. Yount KM, Zureick-Brown S, Salem R. Intimate partner violence and women's economic and non-economic activities in Minya, Egypt. Demography. 2014;51(3):1069-99. http://doi.org/10.1007/s13524-014-0285-X

30. Egypt human development report 2010. Youth in Egypt: building our future. Cairo: United Nations Development Programme, Institute for National Planning; 2010.

31. Kish L. A procedure for objective respondent selection within the household. J Am Stat Assoc. 1949;44(247):380-7. http://doi.org/1 0.1080/01621459.1949.10483314

32. Bandalos DL, Finney SJ. Factor analysis: exploratory and confirmatory. In: Hancock GR, Mueller RO, editors. The reviewer's guide to quantitative methods in the social sciences. New York: Routledge; 2010:93-114.

33. Muthén LK, Muthén BO. Mplus user’s guide, 7th edition. Los Angeles (CA): Muthén \& Muthén; 1998-2012.

34. Gaskin CJ, Happell B. On exploratory factor analysis: a review of recent evidence, an assessment of current practice, and recommendations for future use. Int J Nurs Stud. 2014;51(3):511-21. http://doi.org/10.1016/j.ijnurstu.2013.10.005

35. Fabrigar LR, Wegener DT. Exploratory factor analysis. New York (NY): Oxford University Press; 2012.

36. Yount KM, Crandall A, Cheong YF. Women's age at first marriage and long-term economic empowerment in Egypt. World Dev. 2018;102:124-34. http://doi.org/10.1016/j.worlddev.2017.09.013

37. Govindasamy P, Malhotra A. Women's position and family planning in Egypt. Stud Fam Plann. 1996;27(6):328-40.

38. El-Zanaty F, Way A. Egypt demographic and health survey 2008. Egypt: Ministry of Health and Population, El-Zanaty and Associates, ORC Macro International; 2009.

39. Ewerling F, Lynch JW, Victora CG, van Eerdewijk A, Tyszler M, Barros AJD. The SWPER index for women's empowerment in Africa: development and validation of an index based on survey data. Lancet Glob Health. 2017;5(9):e916-23. https://doi. org/10.1016/S2214-109X(17)30292-9 